\title{
PENGARUH KUALITAS PRODUK DAN HARGA TERHADAP KEPUTUSAN PEMBELIAN PADA PRODUK LULUR MADU IBU SORAYA
}

\author{
Muhammad Syarif \\ Department of Management FEB UMM \\ E-mail : baharunassegaf13@gmail.com
}

\begin{abstract}
The purpose of this study is 1) to know the influence of product quality significantly to the purchasing decision 2) to know the influence of price significantly to the purchasing decision 3) to know the influence of of product quality and price simultaneously to the purchasing decision and 4) to know the variables that influence is dominant among the variables of product quality and price to the purchasing decision. The population of this research is the consumer who to do a purchase on product of Lulur Madu Ibu Soraya, Accidental Sampling technique definable then it can be as much as 100 research samples. Data analysis techniques used in this research is a method of multiple regression analysis. Based on the results of research and discussion by using multiple linear regression analysis that has been done then it can be drawn in summary as follows: 1) Quality product effect significantly to purchase decisions on product of Lulur Madu Ibu Soraya 2) Price effect significantly to purchase decisions on product of Lulur Madu Ibu Soraya. 3) Product quality and price take effect simultaneously to the purchasing decision on product of Lulur Madu Ibu Soraya 4) Product quality the dominant effect of the purchase decision on product of Lulur Madu Ibu Soraya.
\end{abstract}

Keyword: Product Quality, Price And Consumer Purchasing Decision

PENDAHULUAN

Persaingan bisnis yang semakin tajam membuat para pengusaha berlomba-lomba untuk memasarkan produknya dengan menggunakan berbagai strategi untuk memaksimalkan penjualannya. Syarat yang harus dipenuhi oleh suatu perusahaan agar dapat sukses dalam persaingan adalah berusaha mencapai tujuan untuk menciptakan dan mempertahankan pelanggan. Dengan demikian, setiap perusahaan harus mampu memahami perilaku konsumen pada pasar sasarannya, karena kelangsungan hidup perusahaan tersebut sebagai organisasi yang berusaha memenuhi kebutuhan dan keinginan para konsumen sangat bergantung pada perilaku konsumennya. Perilaku konsumen merupakan tindakantindakan individu yang secara langsung terlibat dalam usaha memperoleh, menggunakan, dan menentukan produk dan jasa, termasuk di dalamnya: proses pengambilan keputusan yang mendahului dan mengikuti tindakantindakan tersebut (Engel dkk, 1994:3). Keputusan pembelian merupakan pemilihan dari dua atau 
lebih alternatif pilihan keputusan pembelian. Keputusan untuk membeli dapat mengarah kepada bagaimana proses dalam pengambilan keputusan tersebut dilakukan (Schiffman dan Kanuk 2004:547). Produk yang dibeli haruslah berkualitas, konsumen akan merasa produk tesebut berkualitas apabila produk tersebut dapat memenuhi keinginan dan kebutuhan sesuai dengan yang diharapkan atau melebihi apa yang diharapkan. Kualitas produk merupakan karakteristik produk atau jasa yang tergantung pada kemampuannya untuk memuaskan kebutuhan pelanggan yang dinyatakan atau diimplikasikan (Kotler dan Amstrong 2008 : 272). Kualitas produk yang baik bukan hanya dilihat dari hasil yang didapatkan dari pemakaian suatu produk, tetapi lebih daripada itu juga termasuk bahan-bahan yang digunakan dalam pembuatan produk dan dampak jangka panjang dari penggunanaan produk tersebut. Kualitas suatu produk ditentukan melalui indikator-indikatornya yaitu performance (kinerja), durability (daya tahan), conformance to specifications (kesesuaian dengan spesifikasi), features (fitur), reliability (reliabilitas), aesthetics (estetika), perceived quality (kesan kualitas), serviceability. (Tjiptono, 2008). Faktor lain yang berpengaruh terhadap keputusan pembelian adalah harga (price). Harga adalah sejumlah uang yang dibebankan atas suatu produk, atau jumlah dari nilai yang ditukar konsumen atas manfaatmanfaat karena memiliki atau menggunakan produk tersebut. Pengaruh harga terhadap keputusan pembelian sangatlah penting, karena dengan tingkat harga yang ditetapkan oleh perusahaan dapat menjadi alat pengukur akan permintaan suatu produk. Semakin terjangkau harga suatu produk maka konsumen akan semakin tertarik dan melakukan keputusan pembelian terhadap produk yang bersangkutan (Kotler dan Amstrong 2008:266). Berdasar penjelasan diatas, dapat dilihat bahwa terdapat kaitan erat antara kualitas produk dan harga terhadap keputusan pembelian oleh konsumen.

Berbagai macam produk lulur mandi makin menjamur di kalangan masyarakat dengan berbagai keunggulan yang ditawarkan. Realita yang ada, produk kecantikan khususnya lulur mandi yang ada di pasaran saat ini sebagian besar merupakan racikan dari bahan bahan kimia. Penggunaan produk berbahan kimia dalam jangka panjang akan menimbulkan efek yang merugikan bagi konsumen. Selain itu, perang harga yang acap kali terjadi diantara produsen lulur mandi semakin membuat konsumen bingung. Konsumen seperti yang diketahui, menginginkan sebuah produk yang berkualitas dengan harga yang murah. Ujungnya hal itulah yang menjadi kesempatan bagi produsen lulur mandi untuk menekan harga semurah mungkin tanpa memperhatikan penggunaan bahan berkualitas dalam proses produksinya. Dalam realitas persaingan produk kecantikan yang semakin marak terjadi, Lulur Madu Ibu Soraya hadir dengan keunikan dan kealamiannya dengan bahan alami andalannya yaitu madu dan minyak zaitun yang tidak diragukan lagi khasiatnya untuk kecantikan kulit. Bahan bahan alami yang terdapat dalam lulur madu menjamin terbebasnya konsumen dari efek 
negatif yang ditimbulkan dalam pemakaian jangka panjang. Harga yang ditawarkan pun walaupun tidak begitu murah, tetapi relatif dapat terjangkau oleh semua kalangan dan dapat bersaing dengan produk pesaing yg sejenis. Hal itu tentu sejalan dengan kualitas yang didapat oleh konsumen. .

Berdasarkan latar belakang penelitian dapat dirumuskan permasalahan yang akan diteliti adalah sebagai berikut: 1) Apakah kualitas produk berpengaruh signifikan terhadap keputusan pembelian pada produk Lulur Madu Ibu Soraya? 2) Apakah harga berpengaruh signifikan terhadap keputusan pembelian pada produk Lulur Madu Ibu Soraya? 3) Apakah kualitas produk dan harga berpengaruh simultan terhadap keputusan pembelian pada produk Lulur Madu Ibu Soraya? 4) Diantara kualitas produk dan harga manakah yang berpengaruh dominan terhadap keputusan pembelian pada produk Lulur Madu Ibu Soraya? Hasil penelitian terdahulu yang digunakan yaitu Ummu Habibah, Sumiati (2015) dengan judul penelitian Pengaruh Kualitas Produk dan Harga Terhadap Keputusan Pembelian Produk Kosmetik Wardah di Kota Bangkalan, Madura. Hasil penelitian menunjukkan bahwa kualitas produk dan harga berpengaruh signifikan secara parsial dan simultan terhadap keputusan pembelian. Variabel dominannya adalah kualitas produk..

\section{TINJAUAN PUSTAKA}

Suatu keputusan dapat dibuat hanya jika ada beberapa alternatif yang dipilih. Apabila alternatif pilihan tidak ada maka tindakan yang dilakukan tanpa adanya pilihan tersebut tidak dapat dikatakan membuat keputusan. Keputusan pembelian timbul karena adanya penilaian objektif atau karena dorongan kebutuhan dan keinginan akan suatu produk atau jasa. Keputusan pembelian adalah pemilihan satu tindakan dari dua atau lebih pilihan alternatif ( Tjiptono 2008:19)

Keputusan pembelian konsumen adalah membeli merek yang paling disukai dari berbagai alternatif yang ada, tetapi dua faktor bisa berada antara niat pembelian dan keputusan pembelian. Faktor pertama adalah sikap orang lain dan faktor yang kedua adalah faktor situasional. Oleh karena itu, preferensi dan niat pembelian tidak selalu menghasilkan pembelian yang aktual (Kotler dan Amstrong 2008:181).

Berdasarkan pendapat ahli diatas dapat disimpulkan keputusan pembelian adalah suatu keputusan seseorang dimana dia memilih salah satu dari beberapa alternatif pilihan yang ada dan proses integrasi yang mengkombinasi sikap pengetahuan untuk mengevaluasi dua atau lebih perilaku alternatif dan memilih salah satunya. Proses keputusan pembelian oleh konsumen dapat dipengaruhi oleh banyak faktor dalam produk, salah satunya kualitas produk dan harga. Kualitas produk merupakan salah satu fokus utama dari perusahaan, kualitas produk merupakan salah satu kebijakan penting meningkatkan daya saing produk yang meliputi daya saing produk yang harus memberi kepuasan kepada konsumen yang melebihi atau paling tidak sama dengan kualitas produk pesaing. 
Menurut Kotler dan Amstrong (2008:272) kualitas produk adalah karakteristik produk atau jasa yang tergantung pada kemampuanya untuk memuaskan kebutuhan pelanggan yang dinyatakan atau diimplikasikan. Menurut Alma (2009:206) menyatakan bahwa kualitas produk adalah seperangkat atribut baik berwujud maupun tidak berwujud, termasuk didalamnya masalah warna, harga, nama baik pabrik, nama baik toko yang menjual (pengecer), dan pelayanan pabrik serta pelayanan pengecer, yang diterima oleh pembeli guna memuaskan keinginannya. Berdasarkan penjelasan diatas, maka dapat disimpulkan bahwa kualitas produk adalah keseluruhan barang dan jasa yang berkaitan dengan keinginan konsumen yang secara keunggulan produk sudah layak diperjualkan sesuai harapan dari pelanggan. Konsumen senantiasa melakukan penilaian terhadap kinerja suatu produk, hal ini dapat dilihat dari kemampuan produk menciptakan kualitas produk dengan segala spesifikasinya sehingga dapat menarik minat konsumen untuk melakukan pembelian terhadap produk tersebut.

Harga adalah nilai suatu barang yang dinyatakan dengan uang (Alma,2004:169). Menurut Tandjung (2004:78), harga merupakan jumlah uang yang telah disepakati oleh calon pembeli dan penjual untuk ditukar dengan barang atau jasa dalam transaksi bisnis normal. Swasta dan Sukotjo (2007:211) mendefinisikan harga adalah sejumlah uang (ditambah beberapa barang kalau mungkin) yang dibutuhkan untuk mendapatkan sejumlah kombinasi dari barang beserta pelayanannya. Sedangkan menurut Cannon,dkk, (2008:176) mendefinisikan harga adalah segala sesuatu yang diberikan oleh pelanggan untuk mendapatkan keunggulan yang ditawarkan oleh bauran pemasaran perusahaan.Juga menurut Kotler dan Amstrong, (2008:345), harga adalah jumlah uang yang ditagihkan atas suatu produk atau jasa.

Penelitian yang dilakukan oleh Pragita Shinta Uli Sitorus (2015) dengan judul Pengaruh Citra Merek, Kualitas Produk dan Harga Terhadap Keputusan Pembelian Pada Produk Wardah menyatakan bahwa variabel kualitas produk berpengaruh secara signifikan terhadap keputusan pembelian. Penelitian yang dilakukan oleh Ummu Habibah, Sumiati (2015) dengan judul Pengaruh Kualitas Produk dan Harga Terhadap Keputusan Pembelian Produk Kosmetik Wardah di Kota Bangkalan, Madura menyatakan bahwa variabel variabel harga berpengaruh secara signifikan terhadap keputusan pembelian. Kerangka pikir pada penelitian ini adalah sebagai berikut



METODE PENELITIAN

Gambar 1. Kerangka Pikir Penelitian 
Penelitian ini dilakukan pada seluruh konsumen Lulur Madu Ibu Soraya di Jawa Timur yang jumlahnya belum diketahui. Dalam penelitian ini Jenis penelitian yang digunakan adalah penelitian survei. Dalam penelitian ini menggunakan data primer. Data primer adalah data yang secara khusus dikumpulkan untuk kebutuhan riset yang sedang berjalan. Dalam hal ini populasi memiliki kesamaan dalam suatu bahkan berbagai hal yang membentuk masalah pokok dalam suatu riset. Berdasarkan dari teori diatas peneliti menetapkan bahwa populasi dari penelitian ini adalah seluruh konsumen Lulur Madu Ibu Soraya.

Teknik yang digunakan dalam pengambilan sampel dalam penelitian ini adalah accidental sampling dengan jumlah sampel sebanyak 100

Tabel 1. Rekapitulasi Hasil Analisis Regresi Berganda Pengaruh Kualitas Produk dan Harga

\begin{tabular}{|c|c|c|c|c|c|c|c|}
\hline \multirow[t]{2}{*}{ Model } & \multicolumn{2}{|c|}{$\begin{array}{c}\text { Unstandardized } \\
\text { Coefficients }\end{array}$} & \multirow{2}{*}{$\begin{array}{c}\begin{array}{c}\text { Standardized } \\
\text { Coefficients }\end{array} \\
\text { Beta }\end{array}$} & \multirow[t]{2}{*}{$\mathrm{T}$} & \multirow[t]{2}{*}{ Sig. } & \multicolumn{2}{|c|}{$\begin{array}{c}\text { Collinearity } \\
\text { Statistics }\end{array}$} \\
\hline & B & Std. Error & & & & $\begin{array}{l}\text { Toleran } \\
\text { ce }\end{array}$ & VIF \\
\hline (Constant) & 3,740 & ,708 & & 5,279 & ,000 & & \\
\hline $\begin{array}{l}\text { Quality } \\
\text { Product }\end{array}$ & , 174 & ,016 & ,732 & 10,980 & ,000 & ,841 & 1,189 \\
\hline Price & ,096 & ,046 & , 139 & 2,089 & ,039 & ,841 & 1,189 \\
\hline
\end{tabular}

a. Dependent Variable: Keputusan Pembelian

Berdasarkan hasil analisis regresi, maka dapat dirumuskan suatu persamaan regresi berganda sebagai berikut:

$$
Y=3,740+0,174 X_{1}+0,096 X_{2}
$$

Dari Tabel 2, maka secara parsial masing - masing variabel bebas berpengaruh terhadap kepuasan responden. Penelitian ini menggunakan teknik Analisis Regresi Linier Berganda. Analisa regresi adalah prosedur statistik untuk menganalisa hubungan antara variable dependen dan variable independen.

\section{HASIL PENELITIAN DAN PEMBAHASAN}

Dalam bagian ini disajikan hasil statistik mengenai pengaruh kualitas produk dan harga terhadap keputusan pembelian, dengan hasil penelitian yang telah diolah komputer melalui program SPSS dengan analisis regresi linier berganda (multiple regression) secara parsial dan simultan. 
$\mathrm{b}_{1}=0,174$ merupakan slope atau koefisien arah variabel kualitas produk $\left(\mathrm{X}_{1}\right)$ yang mempengaruhi upaya untuk keputusan pembelian (Y), artinya variabel kualitas produk berpengaruh positif sebesar 0,174 terhadap upaya untuk keputusan pembelian pada produk Lulur Madu Ibu Soraya, jika variabel lainnya dianggap konstan.

$\mathrm{b}_{2}=0,096$ merupakan slope atau koefisien arah variabel harga $\left(\mathrm{X}_{2}\right)$ yang mempengaruhi upaya untuk keputusan pembelian (Y), artinya variabel harga berpengaruh positif sebesar 0,096 terhadap upaya untuk keputusan pembelian pada produk Lulur Madu Ibu Soraya, jika variabel lainnya dianggap konstan. Dari hasil perhitungan analisis regresi linier berganda yang telah dilakukan menunjukkan kemampuan model dalam menjelaskan pengaruh variabel independent terhadap variabel dependent adalah besar, hal tersebut dapat dilihat pada nilai Adj. R. Square $\left(\mathrm{R}^{2}\right)$ yaitu sebesar 0,630. Dengan demikian berarti bahwa model regresi yang digunakan mampu menjelaskan pengaruh variabel persepsi kualitas produk dan persepsi personal selling terhadap keputusan pembelian konsumen di UD Honda MPM Motor Nganjuk sebesar 63\%, sedangkan sisanya sebesar $37 \%$ dijelaskan oleh variabel variabel lain yang tidak termasuk dalam penelitian ini.

Berdasarkan hasil analisis maka hasil uji F dapat disajikan pada Tabel 3.

Tabel 2. Hasil Uji F

\begin{tabular}{lll}
\hline Hipotesis Alternatif $\left(\mathrm{H}_{\mathrm{a}}\right)$ & $\mathrm{F}_{\text {tabel }}$ & Keterangan \\
\hline $\begin{array}{l}\text { Terdapat pengaruh yang signifikan } \\
\text { secara simultan dari variabel kualitas } \\
\text { produk dan harga keputusan }\end{array}$ & $\mathrm{F}_{\text {hitung }}=85,162$ & $\mathrm{H}_{\mathrm{a}}$ diterima/ \\
$\begin{array}{l}\text { pembelian pada produk Lulur Madu } \\
\text { Ibu Soraya (Y) }\end{array}$ & Sig. F $=0,000$ & $\mathrm{H}_{\mathrm{O}}$ ditolak \\
& &
\end{tabular}

Sumber: Data primer diolah

Tabel 3. Perbandingan Antara Nilai thitung Dengan tTabel

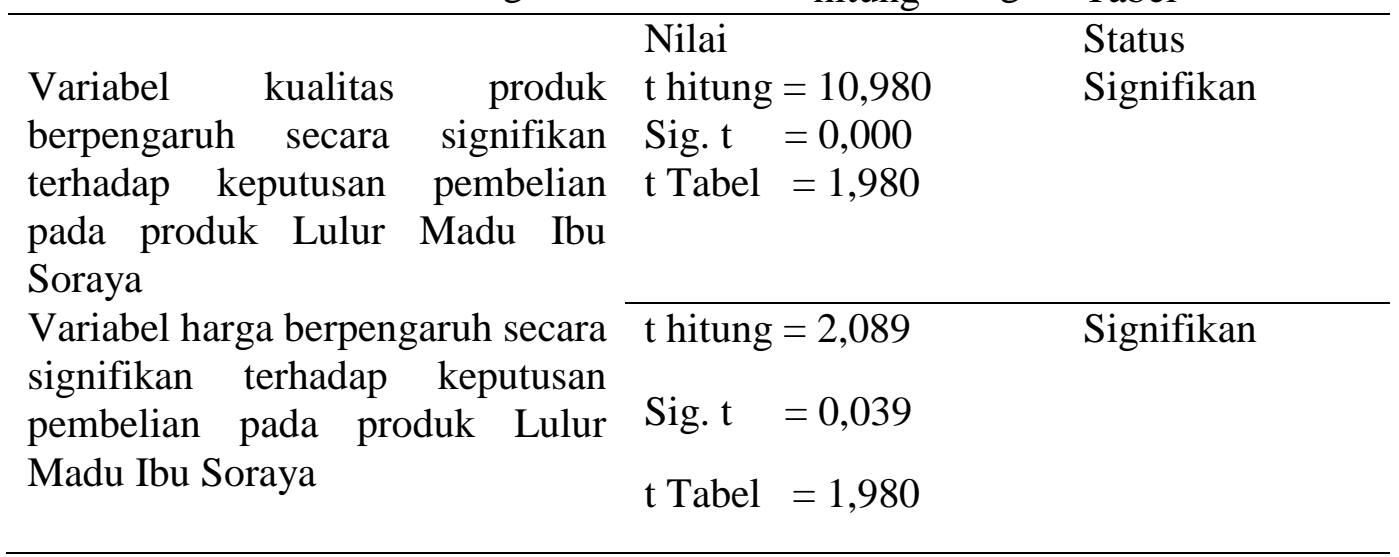


Adapun untuk mengetahui besarnya pengaruh variabel bebas terhadap variabel terikat maka dapat diketahui dari hasil perbandingan koefisien regresi masing - masing variabel. Dengan menggunakan koefisien regresi masing - masing variabel sehingga mampu mengeliminasi perbedaan unit ukuran pada variabel independent (bebas) yang terdiri dari variabel kualitas produk $\left(\mathrm{X}_{1}\right)$ dan persepsi harga $\left(\mathrm{X}_{2}\right)$.

Tabel 5 Standardized Coeficient Beta

\begin{tabular}{lc}
\hline Variabel & Standardized Coeficient Beta \\
\hline Kualitas produk & 0,732 \\
Harga & 0,139
\end{tabular}

\section{Sumber: Data Primer Diolah}

\section{Berdasarkan hasil} Standardized Coefficients Beta dapat dilihat nilai masing - masing variabel memiliki nilai berbeda. Jika dibanding dengan nilai variabel persepsi harga maka nilai variabel kualitas produk memiliki nilai terbesar yaitu 0,732. Hal ini menunjukkan bahwa kualitas produk mempunyai pengaruh dominan terhadap keputusan pembelian konsumen pada produk Lulur Madu Ibu Soraya.

Berdasarkan hasil penelitian dan pembahasan yang telah dilakukan maka hasil analisis dapat diketahui bahwa terdapat pengaruh yang signifikan antara kualitas produk terhadap keputusan pembelian pada produk Lulur Madu Ibu Soraya. Adanya pengaruh yang signifikan menunjukkan bahwa dengan semakin baiknya kualitas produk maka keputusan pembelian pada produk Lulur Madu Ibu Soraya akan mengalami peningkatan. Kondisi tersebut menunjukkan bahwa dengan semakin baiknya kualitas produk dalam hal ini mengenai perfomance, durability, conformance to specifications, features, reliability, aesthetics, perceived quality dan serviceability maka dapat meningkatkan keputusan pembelian konsumen. Penelitian ini mendukung hasil penelitian terdahulu yang dilakukan oleh Pragita Shinta Uli Sitorus (2015) yang menyatakan bahwa kualitas produk berpengaruh signifikan terhadap keputusan pembelian konsumen. Penelitian ini didukung juga oleh teori yang dikemukakan oleh Angipora (2002:174) yang menyatakan bahwa kualitas dari setiap produk yang dihasilkan merupakan salah satu unsur yang harus mendapat perhatian yang sungguh - sungguh dari perusahaan, kalau perusahaan ingin memenangkan suatu persaingan dalam usaha. Dengan demikian dapat dikatakan bahwa hipotesis 1 diterima, yang menyatakan bahwa kualitas produk berpengaruh signifikan terhadap keputusan pembelian konsumen pada produk Lulur Madu Ibu Soraya.

Hasil analisis secara parsial dapat diketahui bahwa terdapat pengaruh yang signifikan antara 
harga terhadap keputusan pembelian pada produk Lulur Madu Ibu Soraya. Adanya pengaruh yang signifikan menunjukkan bahwa dengan semakin baiknya harga maka keputusan pembelian pada produk Lulur Madu Ibu Soraya akan mengalami peningkatan. Hal ini menunjukkan bahwa dengan semakin baiknya harga yang berkaitan dengan harga yang terjangkau, harga yang sesuai dengan kualitas, harga yang berdaya saing, dan harga yang sesuai dengan manfaat maka akan meningkatkan keputusan pembelian pada produk Lulur Madu Ibu Soraya . Penelitian ini mendukung hasil penelitian terdahulu yang dilakukan oleh Pragita Shinta Uli Sitorus (2015) yang diperoleh hasil bahwa terdapat pengaruh signifikan antara harga terhadap keputusan pembelian konsumen. Hasil penelitian ini juga didukung oleh teori yang dikemukakan oleh Swastha dan Sukotjo (2007:211) yang menyatakan bahwa penentuan harga merupakan salah satu keputusan penting bagi manajemen. Harga yang ditetapkan harus dapat menutup semua ongkos, atau bahkan lebih dari itu yaitu mendapatkan laba. Tetapi, jika harga ditentukan terlalu tinggi akan berakibat kurang menguntungkan. Dalam hal ini pembeli akan berkurang, volume penjualan berkurang, semua biaya mungkin tidak dapat ditutup dn akhirnya perusahaan akan menderita. Salah satu prinsip bagi manajemen dalam penentuan harga ini adalah menitikberatkan pada kemauan pembeli untuk harga yang telah ditentukan dengan jumlah yang cukup untuk menutup ongkos ongkos dan menghasilkan laba.. Dengan demikian dapat dikatakan bahwa hipotesis 2 diterima, yang menyatakan bahwa harga berpengaruh signifikan terhadap keputusan pembelian konsumen pada produk Lulur Madu Ibu Soraya.

Berdasarkan hasil analisis penelitian dengan uji $\mathrm{F}$ menunjukkan bahwa terdapat pengaruh secara silmutan antara kualitas produk dan harga terhadap keputusan pembelian pada produk Lulur Madu Ibu Soraya. Hasil tersebut menunjukkan bahwa dengan adanya perubahan atau semakin baiknya kualitas produk dan harga maka keputusan pembelian pada produk Lulur Madu Ibu Soraya juga akan mengalami peningkatan. Dengan demikian dapat dikatakan hipotesis 3 diterima, yang menyatakan bahwa kualitas produk dan harga berpengaruh secara simultan terhadap keputusan pembelian pada produk Lulur Madu Ibu Soraya. Hasil penelitian ini mendukung hasil penelitian terdahulu yang dilakukan oleh Ummu Habibah, Sumiati (2015) yang menyatakan bahwa kualitas produk dan harga berpengaruh secara simultan terhadap keputusan pembelian pada produk Lulur Madu ibu Soraya.

Dari hasil analisis penelitian, variabel yang berpengaruh dominan terhadap keputusan pembelian yaitu terdapat pada variabel kualitas produk. Adanya pengaruh dominan menunjukkan bahwa selama ini konsumen lebih mempertimbangkan kualitas produk yang ada pada produk Lulur Madu Ibu Soraya untuk selanjutnya memutuskan melakukan pembelian. Hasil penelitian ini juga didukung penelitian terdahulu yang dilakukan oleh Ummu Habibah, Sumiati (2015) yang menyatakan 
bahwa kualitas produk memiliki pengaruh dominan terhadap keputusan pembelian.

\section{SIMPULAN}

Berdasarkan hasil penelitian dan pembahasan yang telah dilakukan maka dapat ditarik kesimpulan sebagai berikut yang pertama, kualitas produk berpengaruh signifikan terhadap keputusan pembelian pada produk Lulur Madu Ibu Soraya, kedua, harga berpengaruh signifikan terhadap keputusan pembelian pada produk Lulur Madu Ibu Soraya, ketiga, kualitas produk dan harga berpengaruh secara simultan terhadap keputusan pembelian pada produk Lulur Madu Ibu Soraya, keempat kualitas produk berpengaruh dominan terhadap keputusan pembelian pada produk Lulur Madu Ibu Soraya.

Berdasarkan kesimpulan di atas, maka dapat diajukan beberapa saran yaitu sebagai berikut diharapkan bagi perusahaan untuk terus menjaga dan meningkatkan kualitas produk sehingga semakin memantapkan konsumen untuk membuat keputusan membeli produk Lulur Madu Ibu Soraya, berikutnya perusahaan dalam menetapkan harga harus selalu mempertimbangkan daya beli masyarakat, dengan cara memberikan harga yang terjangkau dan sesuai dengan kualitas produk, untuk menjaga agar para konsumen tetap melakukan keputusan pembelian pada produk Lulur Madu Ibu Soraya, sedangkan berkaitan dengan variabel kualitas produk, konsumen memperhatikan manfaat langsung dari produk, produk yang bertahan lama, memiliki spesifikasi sesuai yang dibutuhkan, memiliki butiran butiran scrubbing, tidak menimbulkan efek samping dalam jangka waktu lama, penampilan kemasan yang menarik dan mudah dibuka, mempunyai sertifikat Intertek Internasional dan ijin BPOM, serta tersedia ruang komplain, kritik dan saran. Sama halnya dengan variabel harga, konsumen memperhatikan harga produk yang relatif dapat dijangkau semua kalangan, harga produk yang sejalan dengan kualitas yang didapat, harga produk yang dapat bersaing dengan produk pesaing, harga produk yang sesuai dengan manfaat yang didapat. Oleh karena itu, diharapkan perusahaan harus sama-sama memperhatikan kualitas produk dan harga, karena kedua variabel tersebut sama-sama berpengaruh terhadap keputusan pembelian produk Lulur Madu Ibu Soraya.

Sebagai salah satu unsur yang paling berpengaruh dalam keputusan pembelian konsumen, perusahaan harus memberikan perhatian penuh pada kualitas produk yang meliputi, performance, durability, conformance to specifications, features, reliability, aesthetics, perceived quality dan serviceability, sehingga konsumen mengerti dan semakin yakin akan keunggulan produk Lulur Madu Ibu Soraya yang berbahan alami yang pada ujungnya konsumen akan melakukan pembelian secara berkelanjutan.

Bagi peneliti selanjutnya yang berminat untuk melanjutkan penelitian ini diharapkan untuk menyempurnakannya, yaitu dengan menggunakan obyek atau variabel lain yang berpengaruh terhadap keputusan pembelian konsumen dan diharapkan untuk menambah jumlah 
sampel penelitian, dengan harapan penelitian ini dapat lebih berkembang.

\section{DAFTAR PUSTAKA}

Adji, Pricilia. 2013. "Pengaruh Retail

Mix Terhadap Keputusan

Pembelian Mahasiswa UK

PETRA di Circle K

Siwalankerto Surabaya".

Jurnal Manajemen Pemasaran

Petra Vol.1, No.2.

Alma, Buchari. 2004. Manajemen

Pemasaran dan Pemasaran

Jasa. Bandung. Alfabeta. 2009. Manajemen

Pemasaran Dan Pemasaran Jasa. Bandung. Alfabeta 2011. Manajemen

Pemasaran dan Pemasaran Jasa. Bandung. Alfabeta

Angipora, Marius P. 2002. Dasar-

Dasar Pemasaran. Edisi

Kedua. Cetakan Kedua.

Jakarta. Raja Grafindo

Persada.

Arikunto, Suharsimi. 2006. Prosedur

Penelitian (Suatu Pendekatan

Praktik). Jakarta. Renika Cipta

Cannon, Joseph P. Perreault, William

D. McCarthy, Jerome. 2008.

Pemasaran Dasar. Buku 1

Edisi 16. Jakarta. Salemba

Empat.

Cannon, Perreault dan McCarthy. 2009. Pemasaran Dasar Pendekatan Manajerial Global. Buku 2 Edisi 16. Jakarta. Salemba Empat

Engel, James F. Blackwell, Roger D.

Miniard, Paul W. 1994.

Perilaku Konsumen. Edisi

Keenam. Jilid 1. Jakarta.

Binarupa Aksara o Semarang.

Ghozali, Imam. 2001. Aplikasi Analisis Multivariate Dengan
Program SPSS. Semarang.

Badan Penerbit Universitas Diponegoro

2005. Aplikasi

Analisis Multivariate Dengan Program SPSS. Semarang. UNDIP.

Kotler, Philip. 2000. Manajemen Pemasaran. Jilid 1. Edisi Milenium. Jakarta. Prehallindo.

Kotler, Philip dan Amstrong, Gary. 2004. Prinsip-Prinsip Marketing. Edisi Ketujuh. Jakarta. Salemba Empat

$2008 . \quad$ Prinsip-prinsip

Pemasaran. Jilid 2. Edisi

Keduabelas. Jakarta. Erlangga.

Kotler, Philip dan Keller, Kevin. 2009. Manajemen Pemasaran.Jilid 1 Edisi Ketigabelas.Jakarta. Erlangga

$2009 . \quad$ Manajemen

Pemasaran.Jilid 2 Edisi Ketigabelas.Jakarta. Erlangga.

Lamb, Charles W. Hair, Joseph F. McDaniel, Carl. 2000. "Pemasaran". Buku 1. Jakarta. Salemba Empat

Maholtra, K ,Naresh. 2004 , Riset Pemasaran Pendekatan Terapan Edisi Bahasa Indonesia . Jakarta. PT. Indeks Kelompok Gramedia

Purnama, Nursya'bani. 2006. Manajemen Kualitas, Perspektif Global. Yogyakarta. Ekonesia.

Santoso, Singgih. 2002. Mengolah Data Statistik secara Professional. Elex Media Komputindo. Jakarta 
Schiffman,Leon G. Leslie, Lazar

Kanuk. 2004. Perilaku

Konsumen. Edisi Ketujuh.

Jakarta. Pretice hall.

Swastha, Basu dan Sukotjo, Ibnu. 2007. Pengantar Bisnis Modern. Yogyakarta. Liberty. Yogyakarta.

Sugiyono. 2005. Memahami Penelitian Kualitatif. Alfabeta. Bandung.

Tandjung, J.W., 2004. Marketing Management: Pendekatan Pada Nilai-Nilai Pelanggan. Edisi Kedua. Cetakan Kedua. Malang. Bayumedia Publishing
Tjiptono, Fandy. 2008. Strategi Pemasaran. Yogyakarta. Andi Umar, Husein. 2000. Umar, Husein. 2000. Metodologi Penelitian. Gramedia Pustaka Umumu. Jakarta.

. 2002. Riset Pemasaran dan Perilaku Konsumen. Cetakan Kedua. Gramedia Pustaka Umum. jakarta 2004. Metode Penelitian Untuk Skripsi dan Tesis Bisnis. Cetakan Keenam, Jakarta. PT Grafindo Persada

Widayat. 2004. Riset Bisnis. Edisi 1. Malang. CV. Cahaya Press 